\title{
WATER CONSUMPTION AND SOIL MOISTURE DISTRIBUTION IN MELON CROP WITH MULCHING AND IN A PROTECTED ENVIRONMENT ${ }^{1}$
}

\author{
RODRIGO OTÁVIO CÂMARA MONTEIRO², RUBENS DUARTE COELHO ${ }^{3}$, \\ PRISCYLLA FERRAZ CÂMARA MONTEIRO ${ }^{4}$, JAN WHOPMANS ${ }^{5}$, BERND LENNARTZ
}

ABSTRACT - Mulching has become an important technique for land cover, but there are some technical procedures which should be adjusted for these new modified conditions to establish optimum total water depth. It is also important to observe the soil-water relations as soil water distribution and wetted volume dimensions. The objective of the present study was to estimate melon evapotranspiration under mulching in a protected environment and to verify the water spatial distribution around the melon root system in two soil classes. Mulching provided $27 \mathrm{~mm}$ water saving by reducing water evaporation. In terms of volume each plant received, on average, the amount of $175.2 \mathrm{~L}$ of water in 84 days of cultivation without mulching, while when was used mulching the water requirement was $160.2 \mathrm{~L}$ per plant. The use of mulching reduced the soil moisture variability throughout the crop cycle and allowed a greater distribution of soil water that was more intense in the clay soil. The clayey soil provided on average $43 \mathrm{~mm}$ more water depth retention in $0.50 \mathrm{~m}$ soil deep relative to the sandy loam soil, and reduced $5.6 \mathrm{~mm}$ the crop cycle soil moisture variation compared to sandy loam soil.

Index terms: Evapotranspiration, plastic cover, tensiometer, irrigation.

\section{CONSUMO HÍDRICO E DISTRIBUIÇ̃̃O DA UMIDADE DO SOLO CULTIVADO COM MELÃO SOB MULCHING EM AMBIENTE PROTEGIDO}

RESUMO - O “mulching” tem assumido importante papel na cobertura dos solos, no entanto existem alguns procedimentos técnicos a serem ajustados para as novas condições modificadas para o estabelecimento da necessidade total adequada de água à cultura. É necessário, ainda, observar os processos de distribuição da água no solo e a conformação do bulbo molhado que justifiquem a utilização de tais técnicas. Por conseguinte, este trabalho teve por objetivo quantificar o consumo real de água pela cultura do melão rendilhado em ambiente protegido sob "mulching" e verificar a distribuição espacial de água ao redor do sistema radicular, em duas classes de solo, franco-arenoso e argiloso. O "mulching" permitiu a economia de $27 \mathrm{~mm}$ de água ao reduzir a evaporação de água. Em termos de volume, cada planta recebeu, em média, a quantia de 175,2 L de água nos 84 dias de cultivo, enquanto nos tratamentos com "mulching", a necessidade hídrica foi de 160,2 L de água por planta. A utilização do "mulching" favoreceu a redução na variabilidade da umidade ao longo do ciclo da cultura e permitiu maior distribuição de água no solo, com maior intensidade no argissolo. O Argissolo proporcionou a retenção de $43 \mathrm{~mm}$ a mais que o Latossolo na camada que abrange até 50 $\mathrm{m}$ de profundidade e reduziu $5,6 \mathrm{~mm}$ a variação de umidade do solo durante o ciclo da cultura, comparado ao Latossolo.

Termos para indexação: evapotranspiração, cobertura plástica, tensiômetro.

\footnotetext{
${ }^{1}$ (Trabalho 175-12). Recebido em: 05-06-2012. Aceito para publicação em: 30-04-2013. Com auxílio financeiro para o experimento pelo CNPq, e bolsa pela CAPES

${ }^{2} \mathrm{Eng}^{\mathrm{o}} \mathrm{Agr}^{\circ}$, Dr., Prof. Instituto Federal de Educação, Ciência e Tecnologia do Rio Grande do Sul (IFRS-BG), Osvaldo Aranha 540 - CEP 95700-000, Bento Gonçalves-RS. E-mail: rodrigo.monteiro@bento.ifrs.edu.br

${ }^{3}$ Eng $^{\circ}$ Agr $^{\circ}$, Dr., Prof. Universidade de São Paulo/ESALQ, Av. Pádua Dias 11, CEP 13418-900,Piracicaba-SP. E-mail: rdcoelho@esalq.usp.br ${ }^{4} \mathrm{Eng}^{\mathrm{O}} \mathrm{Agr}^{\mathrm{o}}$, Pesquisadora da Fundação Estadual de Pesquisa Agropecuária (FEPAGRO), Escola de Agronomia, Av. Bento Gonçalves, 7712, CEP 13418-900, Porto Alegre-RS. E-mail: pferrazcm@gmail.com

${ }^{5}$ Prof. PhD, Land, Air and Water Resources, University of California, EUA (UCDavis) Office: Veihmeyer 110 Phone: 530-752-3060 E-mail: jwhopmans@ucdavis.edu

${ }^{6}$ Prof. PhD, Faculty for Agricultural and Environmental Sciences, University of Rostock, Germany Office: Justus-von-Liebig-Weg 6 , 18051 Rostock room: 32 Phone: 0381/ 4983180 . E- mail: bernd.lennartz@uni-rostock.de
} 


\section{INTRODUCTION}

Although melon production is significantly concentrated in the Brazilian states of Rio Grande do Norte and Ceara, in the last two decades there has been an increase in the net melon production in cropped in protected environments in Southeastern (CASTOLDI et al., 2008; PADUAN et al., 2007) and in the North of Brazil (ARAÚJO et al., 2010). This is because increased profitability can be achieved in small areas in a protected environment.

Irrigation is required in fruit growing in protected environments. However, in times of qualitative and quantitative scarcity, water is no longer free property and acquires an economic value (DIAS et al., 2012). Thus water use efficiency has become an everyday need for many users (MONTEIRO et al., 2007). This fact makes the need clear for more rational use within the economic considerations inherent in any productive activity, using techniques that allow efficient water use in various human activities, including irrigation (MONTEIRO et al., 2008a; MONTEIRO et al., 2008b).

The search for this efficiency has led to more efficient application techniques with maximum waste reduction. The use of plastic films in greenhouses and land cover ("mulching") has become critically important for reducing loss water through evaporation (MONTEIRO et al., 2008a). The mulching technique has assumed an important role in land cover (MONTEIRO et al., 2008a; MONTEIRO et al., 2008b; MEDEIROS et al., 2006, MEDEIROS et al., 2005 ), but the actual water use by crops should be observed under these conditions and the soil-waterplant processes involved, soil water distribution and wet bulb conformation, which justify the use of such techniques. This information is of great importance to both, design projects and irrigation management, for example, to define the number and spacing of emitters, their location relative to plants or plant rows and to define the different areas of water and nutrients.

The choice of mulching and protected environment can prolong the melon cropping from spring to autumn and has been shown to be economically viable. However, some technical procedures should be adjusted for the proper conduction of this crop and the solution of problems caused by modifying its environment, including the difficulty of establishing the adequate water allocation. Therefore, the objective of the present study was to quantify the water consumption of a melon plant subjected to the effects of plastic ground cover (mulching) in a protected environment and to verify the spatial distribution of water around the root system of the melon crop in two soil classes: Typic (sandy loam soil) and Ultisol (clayey soil).

\section{MATERIAL AND METHODS}

This study was conducted at the experimental site of the Biosystem Engineering Department, in the "Luiz de Queiroz"Agricultural College - ESALQ / USP, in a protected area of 330 $\mathrm{m}^{2}(22.0 \mathrm{mx} 15 \mathrm{~m})$, located in Piracicaba, state of Sao Paulo, Brazil, at latitude $22^{\circ} 42$ ' $30^{\prime}$ ' S, longitude $47^{\circ} 30^{\prime} 00^{\prime \prime}$ and $546 \mathrm{~m}$ altitude. The climate is Cwa according to Köppen, i.e., humid subtropical climate with a dry winter and $1280 \mathrm{~mm}$ mean rainfall. Climatic data for the experimental period, from September 2005 to January 2006, were obtained from the meteorological station of the Exact Sciences Department ESALQ / USP, located about $500 \mathrm{~m}$ away from the experimental area.

The experiment was carried out in greenhouses covered with high density transparent polyethylene film, $0.10 \mathrm{~mm}$ thick and treated against the action of ultraviolet rays. The sides had a 0.20 $\mathrm{m}$ reinforced concrete wall and were closed with transparent protective plastic screen, type clarite $50 \%$, with ultraviolet protection. The greenhouse contained 96 boxes of $1.0 \mathrm{~m}^{2}$ and $0.65 \mathrm{~m}$ height distributed in eight rows of 12 boxes, four rows of boxes filled with sandy loam soil and four filled with clay soil. Each experimental plot size was 2.0 $\mathrm{m}^{2}$, it was composed of two plants (two boxes). A 5 $\mathrm{cm}$ thick layer of gravel was placed on the bottom of the boxes, covered with "Bidim" geotextile. A $25 \mathrm{~mm}$ diameter PVC pipe was installed, perforated and covered at the bottom with the same geotextile and buried vertically in the ground, serving as a drain.

The following soils were used in this study: Oxisol, Sandy loam, called "Sertãozinho Series" and Ultisol, clay, called "Luiz de Queiroz Series" (Tabela 1). To check the soil water distribution, two variables were studied: ground cover (with and without mulching) and soil class (sandy loam and clay). The melon crop water uptake was estimated with and without plastic ground covering. The plastic film used in the experiment, made in Israel, has the following specifications: double-sided (silver on the upper side and black on the underside), 25 micron thick, $28 \mathrm{MPa}$ stress fracture toughness, $400 \%$ elongation up to fracture, photosynthetically active radiation and less than $1 \%$ reflection of photosynthetically 
active radiation greater than $25 \%$. Twelve boxes were selected with sandy-loam soil and 12 others with clay soil to monitor soil moisture via digital tensiometer puncture (SILVA et al., 2004). The equipment was arranged in the same way as the cultivation boxes, with radial distance from the drip of $0.10,0.20$ and $0.30 \mathrm{~m}$ in the boxes without "mulching." In the boxes with mulching and the distances listed, other equipment was added at the radial distance of $0.40 \mathrm{~m}$ at 43 days after transplanting (DAT). In each of these horizontal distances, equipment was installed at depths of $0.15,0.30$ and $0.50 \mathrm{~m}$. Thus nine tensiometers were placed in 12 monitored boxes without "mulching" and 12 tensiometer in 12 boxes with mulching, being 6 boxes for each soil class.

The crop used in the present study was the net melon (Cucumis melo L.) lacey, hybrid, Bonus II, conducted under staking. The seeds were sown in128-cell trays, and 21 days after sowing (DAS), when plants had two true leaves, they were transplanted to the greenhouse boxes, on November $4^{\text {th }}, 2005$. The melon cycle consisted, from the beginning of transplantation to the last harvest, of an 84-day interval.

The irrigation system used in the experiment was localized, through a drip composed of four lines, $16 \mathrm{~mm}$ nominal diameter polyethylene derivatives and the side lines were of the same material and diameter. The drips were self-compensating, with a $4 \mathrm{~L} \mathrm{~h}^{-1}$ a flow rateoperated at $150 \mathrm{kPa}$ operating pressure. The water suction and distribution to the plants were made by a $0.5 \mathrm{hp}$ centrifugal hydraulic pump, installed inside the greenhouse. After the pump, a filter disk and a Bourdon gauge were installed to monitor the operating pressure of the system.

Irrigation management was based on soil moisture data, obtained by using tensiometers and water retention curves of soil water, prepared in the laboratory. A one-day fixed irrigation shift was established and from the average of the tensiometer readings at $0.15 \mathrm{~m}$ depth observed in the treatments with mulching, the amount of water was set to be applied in all treatments, sufficient to raise the moisture to field capacity, corresponding to the matric potential $(\varphi \mathrm{m})$ of $-10 \mathrm{kPa}$. This management was adopted due to the limitation of the irrigation system, which, for reasons of cost and operability, the water could not be controlled in each treatment individually.

For further analysis of the effect of management type on the boxes without "mulching", evapotranspiration was estimated in these boxes (ETc) and compared with the total depth applied during the experimental period. The PenmanMonteith - FAO Standard test was adopted to estimate the ETo (Allen et al., 1998) (eq. 1), using the value of $0.063 \mathrm{kPa}^{\circ} \mathrm{C}^{-1}$ for the psychrometric constant. To estimate the ETo in the greenhouse from the ETo in the external environment, equation (2) was used, proposed by Blanco and Folegatti (1998) from an experimental study in the same area. The values of crop coefficient $(\mathrm{Kc})$ were adopted according to equation 3 suggested by Silva et al. (2004) who worked with the same cultivar and adopted the same management in the same experimental area.

$$
E T o=\frac{0.408 s\left(R_{n}-G\right)+\frac{\gamma 900 U_{2}\left(e_{s}-e_{a}\right)}{T+273}}{s+\gamma\left(1+0.34 U_{2}\right)}
$$

where:

ETo - hypothetical reference crop evapotranspiration rate, in $\mathrm{mm} \mathrm{d}^{-1}$;

$\mathrm{Rn}$ - net radiation, in $\mathrm{MJ} \mathrm{m}^{-2} \mathrm{dia}^{-1}$;

$\mathrm{G}$ - soil heat flux, in $\mathrm{MJ} \mathrm{m}{ }^{-2} \mathrm{dia}^{-1}$;

$\gamma$ - psychrometric constant, in $\mathrm{kPa}^{\circ} \mathrm{C}^{-1}$;

(es - ea) - represents the vapor pressure deficit of the air;

$\mathrm{T}$ - mean air temperature, in ${ }^{\circ} \mathrm{C}$;

$\mathrm{s}$ - slope of the saturation vapor pressure temperature relationship, in $\mathrm{kPa}^{\circ} \mathrm{C}^{-1}$;

$\mathrm{U} 2$ - wind speed at $2 \mathrm{~m}$ above the ground, in $\mathrm{m} \mathrm{s}^{-1}$;

$$
y=(0.6797 x)+0.4727 \quad r^{2}=0.91
$$

where:

$\mathrm{y}$ - ETo estimated for the protected environment, in mm day ${ }^{-1}$;

$\mathrm{x}$ - ETo in external environment, in $\mathrm{mm}_{\text {day }}{ }^{-1}$.

$$
K_{c}=-0.0003 D A P^{2}+0.0431 D A P-0.4184 \quad r^{2}=0.76
$$

where:

DAP - days after planting.

\section{RESULTS AND DISCUSSION}

During the crop cycle the maximum temperature inside the greenhouse and the external environment were 36.7 and $29.9^{\circ} \mathrm{C}$, respectively, representing a significant difference of approximately $7^{\circ} \mathrm{C}$. The average minimum temperature, determined for the inside and outside the greenhouse, was 19.5 and $18.2^{\circ} \mathrm{C}$ for the experimental period, respectively, differing by approximately $1{ }^{\circ} \mathrm{C}$. The optimum temperature range for the best production growth throughout the melon development cycle is 
between 25 and $35^{\circ} \mathrm{C}$ (OHARA et al., 2000). At low temperatures, $15-20^{\circ} \mathrm{C}$, the melon branch is affected, resulting in poorly developed plants, while very high temperatures, above $35^{\circ} \mathrm{C}$, cause flower and young fruit fall, when accompanied by hot winds, cause cracks in the fruits (OHARA et al., 2000). In just six days of the cycle, the average temperature of the experiment (greenhouse) was less than $25^{\circ} \mathrm{C}$, and no day reached average values greather than $35^{\circ} \mathrm{C}$, although in $75 \%$ of the days, the maximum temperature exceeded $35^{\circ} \mathrm{C}$ and the minimum temperature was below $20^{\circ} \mathrm{C}$ in $39.3 \%$ of the days, which caused no damage to plant (MONTEIRO et al., 2008a).

The average values of temperature measured inside and outside the greenhouse environment for the range of 84 days were 28.1 and $23.4^{\circ} \mathrm{C}$, respectively. Therefore, with these values, the temperature range during the experimental phase allowed good development of the melon crop in the greenhouse. Vásquez (2005) working with the same hybrid melon in the same period of the year and place, from September 2001 to January 2002, found mean values of average temperature, minimum and maximum of $24.9,18,1$ and $33.5^{\circ} \mathrm{C}$, respectively.

The maximum relative humidity $\left(\mathrm{RH}_{\max }\right)$ measured in the environment outside the greenhouse was $99.4 \%$ on average and often equal to $100 \%$, all higher than that measured inside the greenhouse, average $83.8 \%$. Regarding to minimum values, there was observed the same tendency. The air relative humidity value of the external environment, average $55 \%$, was always higher than inside greenhouse, average $30.4 \%$. Vásquez (2005) found values of $72.6,49.8$ and $89.8 \% \mathrm{RH}$ for the average, minimum and maximum relative humidity, respectively, in the same period of the year. These results were expected, since the temperature inside the greenhouse was always higher than the values obtained for the external environment and it is expected that the absolute air humidity would be similar in the two environments. With these values the air relative humidity range during the experimental phase allowed good development of the melon crop in the greenhouse.

The crop evapotranspiration (ETc) boxes without mulching (Figure 1) showed that, in practically the entire crop cycle, the plants without mulching would be under water stress by climatic water balance, contrary to the potential measured on the ground. Due to a problem in the irrigation control panel at 54 DAT, the irrigation system operated for 13 hours, which may have contributed to minimizing the climatic water deficit in cropping boxes without mulching. Despite the climatological total deficit of the crop, as expected due to the management option adopted, there was no negative effect on the development, production and crop quality (MONTEIRO et al., 2008a), showing consistency with the potential measured in the soil.

The total ETc during the cycle was $187.2 \mathrm{~mm}$ and the depth of water applied, $175.2 \mathrm{~mm}$, suspending the irrigation at 81 DAT. This difference of $12 \mathrm{~mm}$, plus the $15 \mathrm{~mm}$ added to the water sheet at 54 DAT (in excess to the boxes with mulching) due to the problem of the irrigation system, expressed therefore, $27 \mathrm{~mm}(14.5 \%)$ water saved due to mulching because water evaporation was prevented. Medeiros et al. (2005) found $18 \%$ reduction in melon water requirement, under the same roof with double-sided silver / black polyethylene film. Dantas et al. 2011 using the same plastic film observed that standard depth of $452 \mathrm{~mm}$ can be reduced by $28 \%$ without yield reduction.

The lowest and highest daily ETc of the crop without "mulching" were recorded at 22 and 75 DAT, respectively, and were 0.4 and $4.9 \mathrm{~mm}$. The average daily ETc was $2.3 \mathrm{~mm}$. Vásquez (2005) in the same place and in the same period of the year, found total depth of $417.3 \mathrm{~mm}$ applied, equivalent to Class A pan evaporation modified in a 94 day cycle, corresponding to a daily average of $4.4 \mathrm{ETc} \mathrm{mm}_{\text {day }}{ }^{-1}$.

In terms of volume, each plant received on average, the amount of $175.2 \mathrm{~L}$ of water at 84 days of cultivation. However, their water uptake, eliminating the error irrigation at 54 DAT, would be $160.2 \mathrm{~L}$ for the mulched boxes. For the boxes without mulching, the water requirement was estimated to be $187.2 \mathrm{~L}$ water per plant. Silva et al. (2004) worked with the same hybrid melon in the same place and time of the year and reported uptake of only $101 \mathrm{~L}$ of water per plant, in an 80-day cycle, because they planted in small potted of $0.06 \mathrm{~m}^{3}$ volume.

During the experimental period, a 231.4 $\mathrm{mm}$ crop water requirement was estimated outside greenhouse. Vásquez (2005) found water requirement of $655.5 \mathrm{~mm}$ outside the greenhouse. The low value found in this study was probably due to climatic conditions inherent at the time of the experiment which compared to the period Vásquez (2005) studied, had lower mean global radiation, daily insolation, and higher relative air humidity. Monteiro et al. (2006) worked in the region of Pentecost, CE, and reported a $422.1 \mathrm{~mm}$ melon water uptake in a 60 day cycle. Ferraz et al. (2011) observed the highest yield of melon is obtained from of $99 \mathrm{~mm} \mathrm{cycle}^{-1}$ plant $^{-1}$ application irrigation depth.

Regarding to soil moisture distribution in 
general, the moisture monitored at a depth of $0.50 \mathrm{~m}$ was higher in the whole cycle, in both soils (Figures 2 and 3), but was more intense in the sandy-loam soil (FA) showing soil water tension, on average, $2.3 \mathrm{kPa}$ compared to $3.1 \mathrm{kPa}$ to the clayey soil (A) (Table 2), showing the greater saturated hydraulic conductivity of this soil (115.8 $\mathrm{mm} \mathrm{h}^{-1}$ for the profile on average) compared to the clay soil (A) that was, on average, $643 \mathrm{~mm} \mathrm{~h}^{-1}$. These conductivity values are related to the accommodation conditions in which the soils were placed in boxes.

The mulching provided on average 35 and 30 $\mathrm{mm}$ water depth retention in $0.50 \mathrm{~m}$ soil deep in the FA and A soil, respectively, compared to no mulching using. The A soil provided on average $43 \mathrm{~mm}$ water depth retention of the same soil deep relative to the FA soil (Table 2).

In the FA soil, the humidity varied greatly (1.6 times of the variation found in the A soil) over the cycle (this means $14.6 \mathrm{~mm}$ compared to $9.0 \mathrm{~mm}$ of the A soil in $0.50 \mathrm{~m}$ soil deep), especially after the 27 DAT, when the plants increased water uptake (Table 2, Figures 2 and 3). This variation was also observed in A soil, but with less intensity, keeping the soil moisture around the field capacity. It was observed that these fluctuations were intensified as the horizontal distance from the drip increased, with the approach of the end of the wet bulb.

It was observed that the A soil moisture, in soil in any position monitored, varied more similarly to moisture at field capacity compared to the soil FA, showing that the matric potential found in the irrigation of $-10 \mathrm{kPa}$ adjusted better to the ground, especially with mulching (Figure 3 ), as shown by better water distribution in the soil, which justified the higher yield found in these conditions (MONTEIRO et al., 2007). Silva et al. (2005), however, worked with the same melon cultivar on sandy-loam soil and took the matric potential of $-10 \mathrm{kPa}$ monitored at 0.15 $\mathrm{m}$ depth and adjusted better to the ground. Braga et al. (2006) studied melon cropping in greenhouses and also found, in contrast to this study, that soil water matric potential from -30 to $-40 \mathrm{kPa}$ at $0.15 \mathrm{~m}$ depth can be used as a criterion to start irrigation in clay textured soil. Measuring soil matric potential at $0.3 \mathrm{~m}$ depth, Rodríguez et al. (1999) showed that the commercial performance of melons was significantly affected by irrigation. The best-yielding treatment corresponded to the matric potential of soil water of $-14 \mathrm{kPa}$. Similarly, Perez \& Rivero (2001) studying total irrigation water for the tensions recorded at $0.3 \mathrm{~m}$ soil depth, $-10,-25$ and $-45 \mathrm{kPa}$ with melon, had better performance for the-10 $\mathrm{kPa}$ treatment. Humidity levels of 25 and $45 \mathrm{kPa}$ negatively affected the total production of fruits by 26 and $30 \%$, respectively.

At 54 DAT, a peak increase in soil moisture was observed for all treatments in both soils and depths monitored, due to excessive water application because of irrigation system problems already mentioned.

The moisture in all treatments decreased considerably in both soils (in the A soil water tension increased $2.4 \mathrm{kPa}$, in average, compared to only 1.2 $\mathrm{kPa}$ of the FA soil) as the radial distance increased from the emitter to the three layers $(0.10,0.30$ and $0.50 \mathrm{~m}$ ) monitored (increased in average $2.5 \mathrm{kPa}$ in the no mulching using compared to increased only $1.0 \mathrm{kPa}$ with mulching using), and the most soil moisture significant reductions were without mulching at a depth of $0.15 \mathrm{~m}$ (Table 2, Figures 2 and 3 ), reducing considerably with soil depth, which characterizes the conformation of the wet bulb around the emitter. This shows the ability of the mulching not only to reduce losses by evaporation, but above all, to promote water distribution in the soil. At a greater horizontal distance from the drip $(0.40 \mathrm{~m})$, the mulching also provided good soil moisture values, demonstrating the important contribution to the horizontal redistribution of soil water. Mota et al. (2010) concluded that the soil cover increased water storage, especially in the initial and rapid growth stages of the crop, but did not influence the fruit yield and post-harvest characteristics. In the FA soil, from 43 DAT (monitoring began at 0.40 $\mathrm{m}$ from the dripper), there was greater fluctuation in moisture until the irrigation was suspended (81 DAT) compared to the A soil, showing that the probable limit of the wet bulb in the FA soil was at this distance, to greater wetting dynamic at the wet bulb limits. 


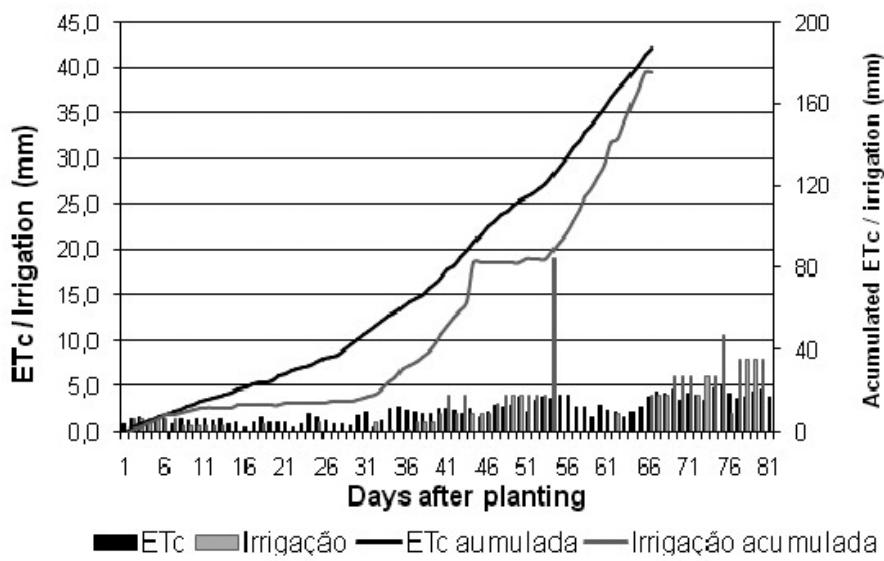

FIGURE1 - Melon evapotranspiration (ETc) in protected environment, without mulching, during the experimental period (81 days) - Piracicaba, SP, 2005

TABLE 1- Soil granulometric composition of both soils: bulk density (Ds), sand, silt, clay and textural classification - Piracicaba, SP, 2005

\begin{tabular}{|c|c|c|c|c|c|}
\hline \multirow{3}{*}{$\begin{array}{c}\text { Layer } \\
(\mathrm{m})\end{array}$} & \multirow{3}{*}{$\begin{array}{c}\text { Ds } \\
\left(\mathrm{g} \mathrm{cm}^{-3}\right)\end{array}$} & \multicolumn{3}{|c|}{ Size fractions } & \multirow{3}{*}{ Texture* } \\
\hline & & Sand & Silt & Clay & \\
\hline & & \multicolumn{3}{|c|}{$(\%)$} & \\
\hline \multicolumn{6}{|c|}{ Oxisol, Sandy loam, called "Sertãozinho Series" } \\
\hline $0-0,20$ & 1,58 & 76 & 4 & 20 & sandy loam \\
\hline $0,20-0,40$ & 1,43 & 74 & 4 & 22 & sandy loam \\
\hline \multicolumn{6}{|c|}{ Ultisol, clay, called "Luiz de Queiroz Series" } \\
\hline $0-0,20$ & 1,20 & 30 & 14 & 56 & Clayey \\
\hline $0,20-0,40$ & 1,11 & 28 & 16 & 56 & Clayey \\
\hline
\end{tabular}

* Santos et al., 2006

TABLE 2- Mean value of soil water tension (Kpa) / mean and standard deviation values of soil moisture* $\left(\mathrm{cm}^{3} \mathrm{~cm}^{-3}\right)$ of both soil in mulching and no mulching conditions, in radial distance from the drip of $0.10,0.30$ and $0.40 \mathrm{~m}$ (added 43 DAT in mulching boxes) at depths of $0.15,0.30$ and $0.50 \mathrm{~m}$ - Piracicaba, SP, 2005

\begin{tabular}{|c|c|c|c|c|c|}
\hline \multirow[t]{2}{*}{ Depth $(\mathrm{m})$} & \multicolumn{5}{|c|}{ Distance from the plant (m) } \\
\hline & \multicolumn{2}{|c|}{0.15} & \multicolumn{2}{|c|}{0.30} & 0.40 \\
\hline \multicolumn{6}{|c|}{ Oxisol, Sandy loam, called "Sertãozinho Series" } \\
\hline & No mulching & Mulching & No mulching & Mulching & Mulching \\
\hline 0.10 & $5.2 / 0.263 \pm 0.026$ & $4.3 / 0.278 \pm 0.022$ & $8.4 / 0.227 \pm 0.039$ & $6.7 / 0.242 \pm 0.039$ & $6.4 / 0.246 \pm 0.040$ \\
\hline 0.30 & $4.0 / 0.313 \pm 0.013$ & $3.8 / 0.315 \pm 0.019$ & $4.5 / 0.308 \pm 0.018$ & $3.9 / 0.314 \pm 0.024$ & $2.7 / 0.330 \pm 0.039$ \\
\hline 0.50 & $2.3 / 0.311 \pm 0.026$ & $2.1 / 0.314 \pm 0.032$ & $2.7 / 0.304 \pm 0.028$ & $2.5 / 0.307 \pm 0.032$ & $1.8 / 0.321 \pm 0.042$ \\
\hline \multicolumn{6}{|c|}{ Ultisol, clay, called "Luiz de Queiroz Series" } \\
\hline & \multicolumn{2}{|c|}{0.15} & \multicolumn{2}{|c|}{0.30} & 0.40 \\
\hline & No mulching & Mulching & No mulching & Mulching & Mulching \\
\hline 0.10 & $9.6 / 0.353 \pm 0.016$ & $4.6 / 0.274 \pm 0.013$ & $16.5 / 0.340 \pm 0.018$ & $7.5 / 0.360 \pm 0.016$ & $9.6 / 0.353 \pm 0.018$ \\
\hline 0.30 & $6.2 / 0.367 \pm 0.020$ & $3.4 / 0.388 \pm 0.021$ & $8.3 / 0.358 \pm 0.025$ & $3.6 / 0.386 \pm 0.013$ & $9.7 / 0.393 \pm 0.032$ \\
\hline 0.50 & $4.6 / 0.437 \pm 0.017$ & $1.6 / 0.458 \pm 0.016$ & $6.6 / 0.430 \pm 0.018$ & $1.8 / 0.456 \pm 0.013$ & $0.8 / 0.474 \pm 0.015$ \\
\hline
\end{tabular}

*CC- soil moisture at field capacity corresponding to the matric potential $(\varphi \mathrm{m})$ of $10 \mathrm{kPa}$ to sandy loam soil $(0,216,0,277$ and 0,251 $\mathrm{cm}^{3} \mathrm{~cm}^{-3}$ to $0.10,0.30$ and $0.50 \mathrm{~m}$ depth, respectively) and clayey soil $\left(0,353,0,352\right.$ and $0,421 \mathrm{~cm}^{3} \mathrm{~cm}^{-3}$ to $0.10,0.30$ and $0.50 \mathrm{~m}$ depth, respectively) 


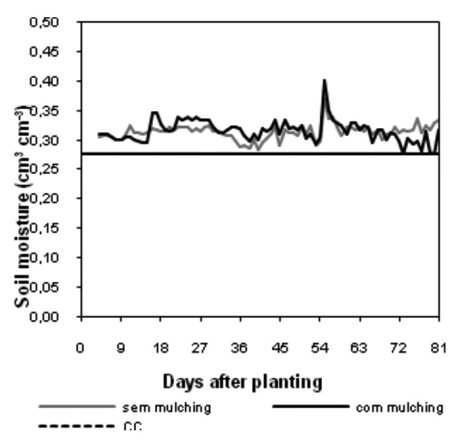

$0.10 \mathrm{~m}$ from the plantand $0.15 \mathrm{~m}$ depth

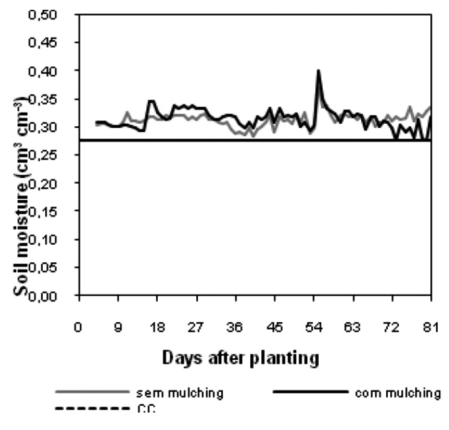

$0.10 \mathrm{~m}$ from the plant and $0.30 \mathrm{~m}$ depth
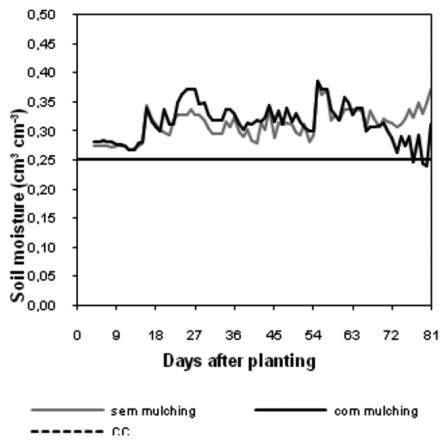

$0.10 \mathrm{~m}$ from the plant and $0.50 \mathrm{~m}$ depth

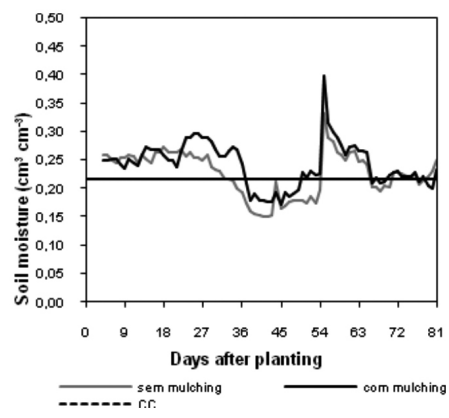

$0.30 \mathrm{~m}$ from the plant and $0.15 \mathrm{~m}$ depth

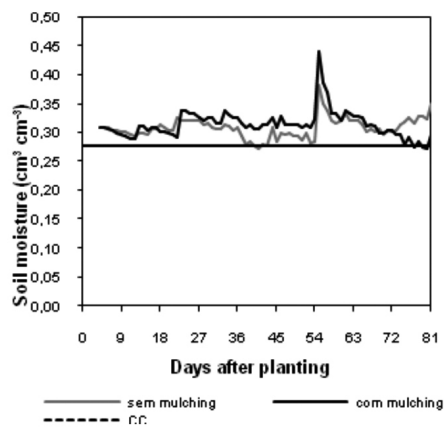

$0.30 \mathrm{~m}$ from the plant and $0.30 \mathrm{~m}$ depth
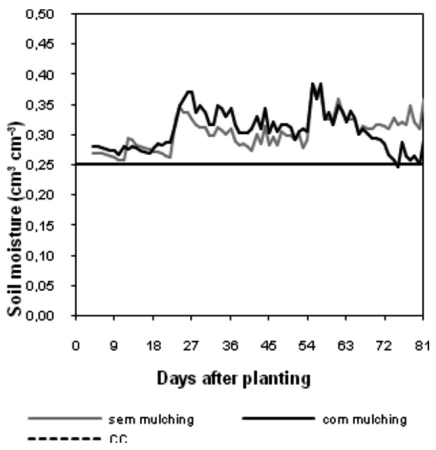

$0.30 \mathrm{~m}$ from the plant and $0.50 \mathrm{~m}$ depth

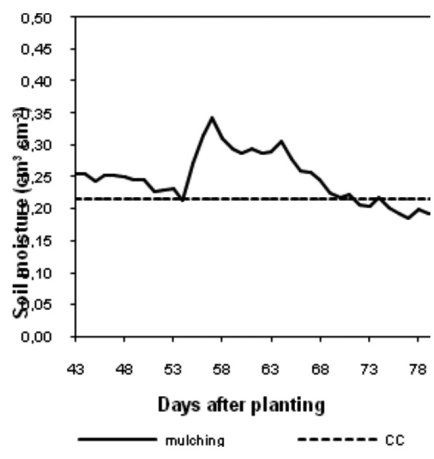

$0.40 \mathrm{~m}$ from the plant and $0.15 \mathrm{~m}$ depth

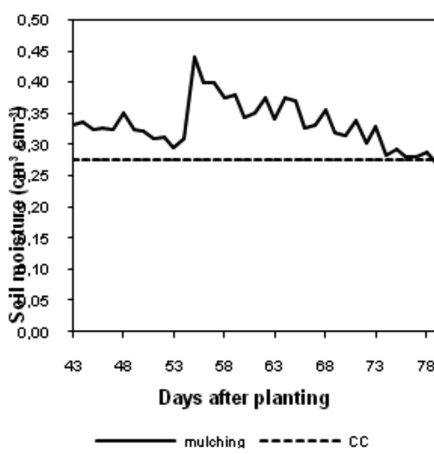

$0.40 \mathrm{~m}$ from the plant and $0.30 \mathrm{~m}$ depth

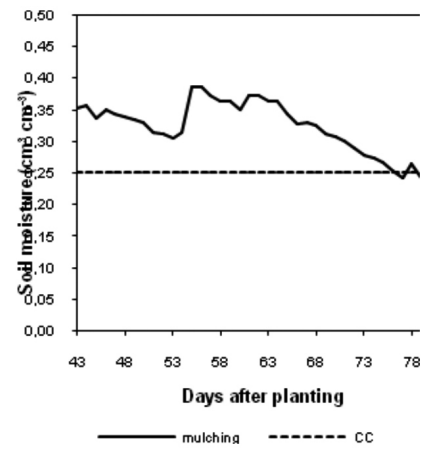

$0.40 \mathrm{~m}$ from the plant and $0.50 \mathrm{~m}$ depth

FIGURE 2 -Variation in soil water content $(\mathrm{cm} 3 \mathrm{~cm}-3)$ during melon cycle, at $0.15,0.30$ and $0.50 \mathrm{~m}$ depths and $0.10,0.30$ and $0.40 \mathrm{~m}$ distances from the drip, in treatments with and without mulching, for sandy loam soil - Piracicaba, SP, Brazil, 2005-2006. 

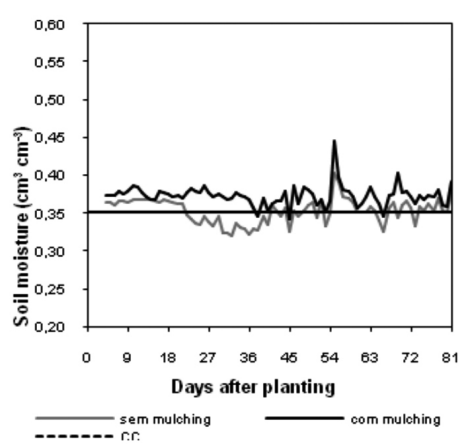

$0.10 \mathrm{~m}$ from the plant and $0.15 \mathrm{~m}$ depth

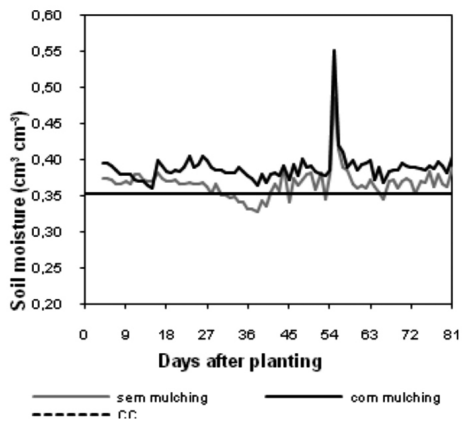

$0.10 \mathrm{~m}$ from the plant and $0.30 \mathrm{~m}$ depth

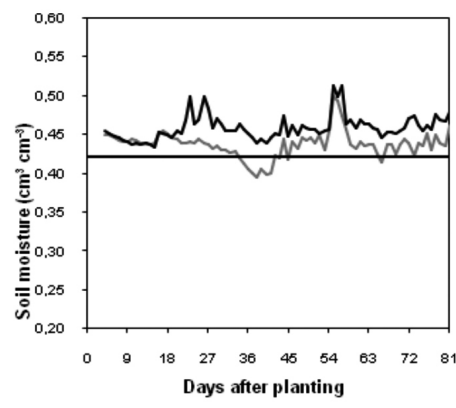

- sem mulching com mulching

$0.10 \mathrm{~m}$ from the plant and $0.50 \mathrm{~m}$ depth
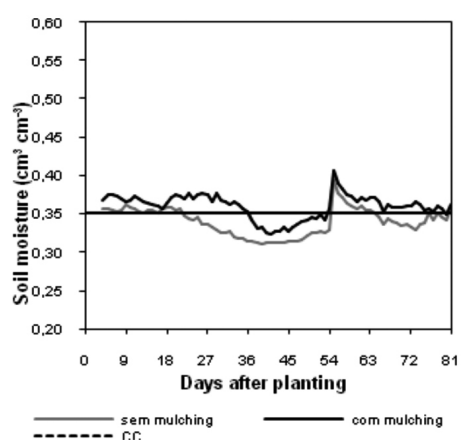

$0.30 \mathrm{~m}$ from the plant and $0.15 \mathrm{~m}$ depth

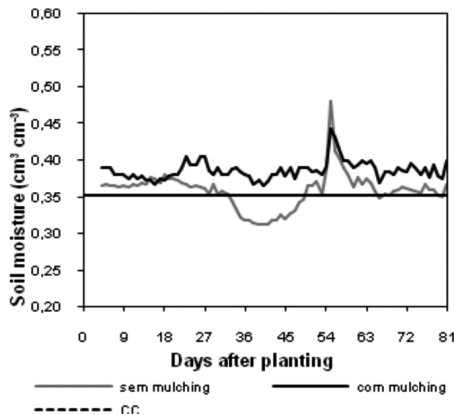

$0.30 \mathrm{~m}$ from the plant and $0.30 \mathrm{~m}$ depth

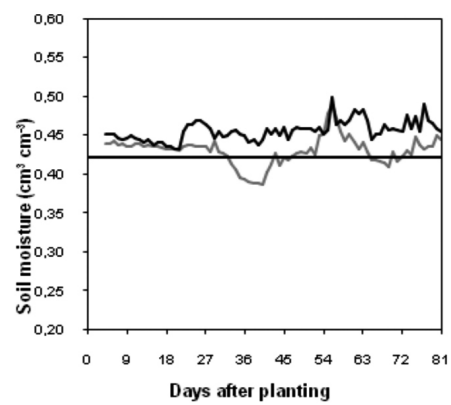

-

$0.30 \mathrm{~m}$ from the plant and $0.50 \mathrm{~m}$ depth
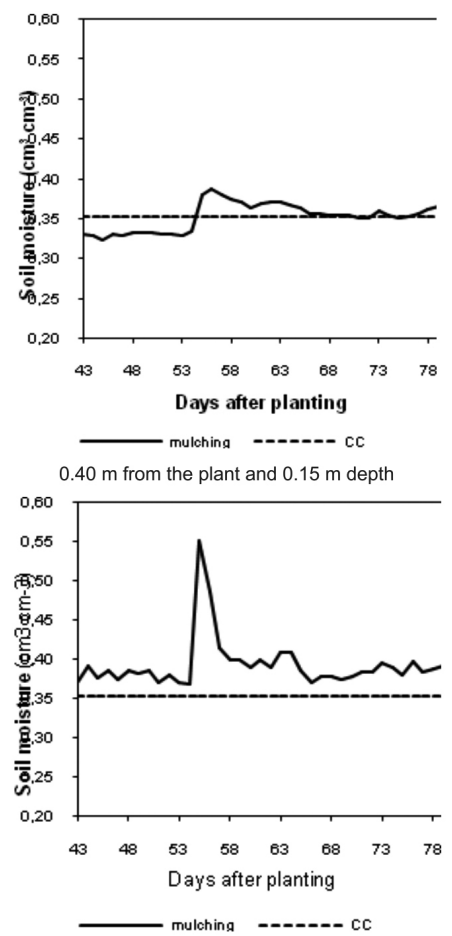

$0.40 \mathrm{~m}$ from the plant and $0.30 \mathrm{~m}$ depth

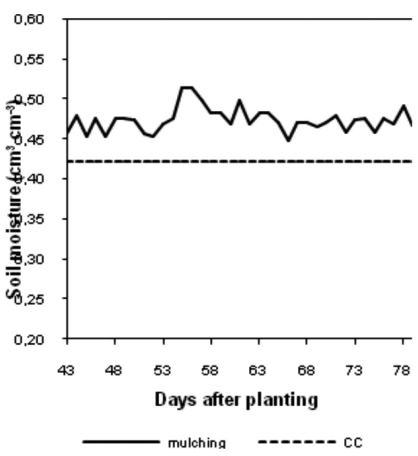

$0.40 \mathrm{~m}$ from the plant and $0.50 \mathrm{~m}$ depth

FIGURE 3 - Variation in soil water content $\left(\mathrm{cm}^{3} \mathrm{~cm}^{-3}\right)$ during melon cycle, at $0.15,0.30$ and $0.50 \mathrm{~m}$ depths and $0.10,0.30$ and $0.40 \mathrm{~m}$ distances from the drip, in treatments with and without mulching, for clay soil - Piracicaba, SP, Brazil, 2005-2006. 


\section{CONCLUSIONS}

Mulching provided $27 \mathrm{~mm}$ water saving by reducing water evaporation. In terms of volume each plant received, on average, the amount of $175.2 \mathrm{~L}$ water in 84 days of cultivation in without mulching, while when was used mulching the water requirement was $160.2 \mathrm{~L}$ per plant. The use of mulching reduced the soil moisture variability throughout the crop cycle and allowed a greater distribution of soil water that was more intense in the clay soil. The clayey soil provided on average $43 \mathrm{~mm}$ more water depth retention in $0.50 \mathrm{~m}$ soil deep relative to the sandy loam soil, and reduced $5.6 \mathrm{~mm}$ the crop cycle soil moisture variation compared to sandy loam soil.

\section{ACKNOWLEDGES}

The authors thank the CNPq and CAPES for financial support.

\section{REFERENCES}

ALLEN, R.G.; PEREIRA, L.S.; RAES, D.; SMITH, M. Crop evapotranspiration: guidelines for computing crop water requeriments. Rome: FAO, 1998. 328 p. (Irrigation and DrainagePaper, 56).

ARAÚJO, W. F.; OLIVEIRA, G. A.; CARVALHO, F. K. de; SILVA, W. M. da; CRUZ, P. L. S.; MACIEL F. C. da S. Manejo da irrigação do meloeiro com base na evaporação do tanque classe A. Horticultura Brasileira, Brasília, v.28, n.4, p.495-499, 2010.

BLANCO, F.F.; FOLEGATTI, M.V. Estimativa da evapotranspiração em estufa plástica utilizando dados meteorológicos externos. In: BALBUENA, R.H.; BENEZ, S.H.; JORAJURÍA, D. (Ed.). Avances em el manejo delsuelo y agua em laingeniería rural latinoamericana. La Plata: UNLP, 1998. p.361-366.

BRAGA, M. B.; DUENHAS, L. H.; SOUZA, C. M. P. de; KLAR, A. E. Orientação geográfica de estufas de polietileno e potenciais de água no solo no cultivo do melão rendilhado híbrido 'nero'. Irriga, Botucatu, v.11, n.1, p.130-138, 2006.

CASTOLDI, R.; CHARLO, H. C. de O.; VARGAS, P. F.; BRAZ, L. T. Qualidade de frutos de cinco híbridos de melão rendilhado em função do número de frutos por planta. Revista Brasileira de Fruticultura, Jaboticabal, v.30, n.2, p.455-458, 2008.
DANTAS, D. da C.; MEDEIROS, J. F. de; FREIRE, A. G. Produção e qualidade do meloeiro cultivado com filmes plásticos em respostas à lâmina de irrigação. Revista Ciência Agronômica, Fortaleza, v.42, n.3, p.652-661, 2011.

DIAS, N. da S.; LIRA, R. B. de; BRITO, R. F.; SOUSA NETO, N. de; FERREIRA NETO, M.; OLIVEIRA, A. M. de. Produção de melão rendilhado em sistema hidropônico com rejeito da dessalinização de água em solução nutritiva. Revista Brasileira de Engenharia Agrícola e Ambiental, Campina Grande, v.14, n.7, p.755-761, 2012.

FERRAZ, R. L. de S.; MELO, A. S. de; FERREIRA, R de S.; DUTRA, A. F.; FIGUEIREDO, L. F. de. Aspectos morfofisiológicos, rendimento e eficiência no uso da água do meloeiro "Gália" em ambiente protegido. Revista Ciência Agronômica, Fortaleza, v.42, n43, p.957-964, 2011.

MEDEIROS, F. A. S. B. de; MEDEIROS, J. F. de; SILVA, M. C. de C.; ALVES, L. P.; SOUZA, T. H. de; LEVIEN, S. L. A. Necessidade hídrica do meloeiro irrigado com água de diferentes salinidades e cultivado com ou sem cobertura do solo. Revista de Engenharia Agrícola e Ambiental, Campina Grande, v.9, n.2, p.234-238, 2005.

MEDEIROS, J. F. de; SILVA, M. C. de C.; CÂMARA NETO, F. G.; ALMEIDA, A. H. B. de; SOUZA, J. de O.; NEGREIROS, M. Z. de; SOARES, S. P. F. Crescimento e produção do melão cultivado sob cobertura de solo e diferentes frequências de irrigação. Revista de Engenharia Agrícola e Ambiental, Campina Grande, v.10, n.4, p.792-797, 2006.

MONTEIRO, R. O. C.; COLARES, D. S.; COSTA, R. N. T.; AGUIAR, J. V. Função de resposta do meloeiro a diferentes lâminas de irrigação e doses de nitrogênio. Horticultura Brasileira, Brasília, v.24, n. 4, p.455-459, 2006.

MONTEIRO, R. O. C.; COELHO, R. D.; MELO, P. C. T. de; FERRAZ, P.; CHAVES, S. W. P. Aspectos produtivos e de qualidade do melão sob gotejo subterrâneo e "mulching" plástico. Acta Scientiarum Agronomy, Maringá, v.29, n.4, p.453457, 2007. 
MONTEIRO, R. O. C.; COELHO, R. D.; MELO, P. C. T. de; FERRAZ, P.; CHAVES, S. W. P.; SHIRAHIGE, F. H.; BELTRAME NETO, E.; PIEDADE, S. M. de S. Net melon performance as affected by the drip irrigation depth and mulching. Horticultura Brasileira, Brasília, v.26, n.4, p.447451, 2008a.

MONTEIRO, R. O. C.; COSTA, R. N. T.; LEÃO, M. C. S.; AGUIAR, J. V. de. Eficiência do uso da água e nitrogênio na produção de melão. Revista Irriga, Botucatu, v.13, n.3, p.367-377, 2008b.

MOTA, J. C. A.; LIBARDI, P. L.; BRITO, A. dos S.; ASSIS JÚNIOR, R. N. de; AMARO FILHO, J. Armazenagem de água e produtividade de meloeiro irrigado por gotejamento, com a superfície do solo coberta e desnuda. Revista Brasileira de Ciência do Solo, Botucatu, v.34, p.1.721-1.731, 2010.

OHARA, T.; KJIMA, A.; WACO, T.; ISHIUCHI, D. Vegetables, ornamental and tea. Bulletin of the National Research Intitute of Tokyo, Tokyo, n. 15, p. 63-69, 2000.

PADUAN, M. T.; CAMPOS, R. P.; CLEMENTE, R. P. Qualidade dos frutos de tipos de melão, produzidos em ambiente protegido. Revista Brasileira de Fruticultura, Jaboticabal, v.29, n.3, p.535-539, 2007.

PÉREZ, Z.O.; RIVERO, M.C. Tensión de humedad del suelo y fertilización nitrogenada enmelón Cantaloupe, híbrido Ovation. Tepames, Colima, México. Agrociencia, Texcoco, v.35, p.479-488, 2001.
RODRÍGUES, C.J.; OCHOA, M.A.; VALENZUELA, I.M. Eficiencia em el uso de agua y nitrógeno por el cultivo de melón (Cucumis melo L.) bajo riego por goteo. In: CONGRESSO NACIONAL DE IRRIGACIÓN, 1999, Culiacán. Proceedings... p. 27-29.

SANTOS, H. G. dos; JACOMINE, P. K. T.; ANJOS, L. H. C. dos; OLIVEIRA, V. A. de OLIVEIRA, J. B. de; COELHO, M. R.; LUMBRERAS, J. F.; CUNHA, T. J. F. (Ed.). Sistema brasileiro de classificação de solos. 2.ed. Rio de Janeiro: Embrapa Solos, 2006. 306 p. il.

SILVA, T.J.A. da; MACHADO, C.C.; SILVA, E.M.B.; COELHO, R.D. Coeficiente de cultivo (Kc) do meloeiro tipo rendilhado cultivado em ambiente protegido. Irriga, Botucatu, v.9, n.1, p.72-81, 2004.

SILVA, T. J. A.; MACHADO, C. C.; SILVA, E. M. B.; COELHO, R. D. Influência do manejo da irrigação no meloeiro rendilhado cultivado em ambiente protegido. Engenharia Agrícola, Jaboticabal, v.25, n.3, p.722-731, 2005.

VÁSQUEZ, M. A. N.; FOLEGATTI, M. V.; DIAS, N. da S.; SILVA, C. R. da. Efeito do ambiente protegido cultivado com melão sobre os elementos meteorológicos e sua relação com as condições externas. Engenharia Agrícola, Jaboticabal, v.25, n.1, p.137-143, 2005. 